\title{
Artikel
}

\section{Follow-on schadeclaims wegens schending van het mededingingsrecht: van law in the books naar law in action}

\section{Inleiding}

Civiele schadeclaims wegens inbreuken op het (Europese) mededingingsrecht zijn inmiddels geen uitzonderlijk verschijnsel meer. Het ligt tegenwoordig in de lijn der verwachting dat na de vaststelling van een kartelinbreuk door de Europese Commissie (of een nationale mededingingsautoriteit) civiele schadeclaims volgen.

Dat is wel anders geweest. Nog in het betrekkelijk recente verleden was de privaatrechtelijke handhaving voornamelijk een interessant onderwerp in het academische debat zonder dat er in de rechtspraktijk daadwerkelijk veel zaken waren te bespeuren. Dit beeld is veranderd. Er is inmiddels een aanzienlijk aantal zaken waarin sprake is van vorderingen tot schadevergoeding wegens mededingingsinbreuken. In vrijwel al deze zaken gaat het om vorderingen die zijn ingesteld nadat de Europese Commissie en/of de nationale mededingingsautoriteit(en) een kartelinbreuk hebben vastgesteld. Het gaat hier - onder meer $-^{1}$ om schadevergoedingsprocedures in het liftenkartel, ${ }^{2}$ het bitumenkartel, ${ }^{3}$ het luchtvracht-

Mr. dr. R. Meijer is advocaat te Amsterdam.

1. Daarnaast zijn er ook claims die nooit zijn aangebracht bij de rechtbank of procedures die zijn ingetrokken, zoals in het geval van de procedure tussen Koninklijke Horeca Nederland en Heineken c.s.

2. Rb. Rotterdam 17 juli 2013, ECLI:NL:RBROT:2013:5504 (Stichting Elevator Claim/Kone c.s.).

3. Rb. Rotterdam 9 februari 2011, ECLI:NL:RBROT:20100:BP7518. kartel, ${ }^{4}$ het paraffinewaskartel, ${ }^{5}$ het natriumchloraatkartel, ${ }^{6}$ het spanstaalkartel en het GIS-kartel. ${ }^{7}$ In de laatstgenoemde procedure is ABB in 2017 veroordeeld tot betaling van schadevergoeding aan Tennet van ruim 23 miljoen euro, te vermeerderen met wettelijke rente. ${ }^{8}$ Dit betrof het eerste vonnis waarin er in een follow-on procedure schadevergoeding is toegekend. Veel van de procedures zijn op dit moment nog aanhangig, al dan niet in hoger beroep. ${ }^{9}$ Er zijn ook diverse nieuwe procedures ophanden c.q. aanhangig waarvan de inhoudelijke behandeling nog moet starten. Het betreft hier bijvoorbeeld procedures in verband met het vrachtwagenkartel, waar diverse claimstichtingen en belangenorganisaties procedures voorbereiden. ${ }^{10}$

Verder is begin 2017 de Implementatiewet privaatrechtelijke handhaving mededingingsrecht in werking getre-

4. O.a. Rb. Amsterdam 12 april 2017, ECLI:NL:RBAMS:2017:2841 (SCC/KLM C.S.); Rb. Amsterdam 13 september 2017, ECLI:NL:RBAMS: 2017:6607 (Equilib/KLM c.s.).

5. O.a. Rb. Den Haag 1 mei 2013, ECLI:NL:RBDHA:2013:CA1870; Rb. Den Haag 21 september 2016, ECLI:NL:RBDHA:2016:11305 (CDC/ Shell c.s.).

6. O.a. Rb. Amsterdam 4 juni 2014, ECLI:NL:RBAMS:2014:3190 (CDC/ Akzo c.s.); Hof Amsterdam 21 juli 2015, ECLI:NL:GHAMS:2015:3006.

7. Rb. Gelderland 16 januari 2013, ECLI:NL:RBONE:2013:BZ0403; Hof Arnhem-Leeuwarden 2 september 2014, ECLI:NL:GHARL:2014:6766; HR 8 juli 2016, ECLI:NL:HR:2016:1483; Rb. Gelderland 29 maart 2017, ECLI:NL:RBGEL:2017:1724 (TenneT c.s./ABB c.s.); Rb. Gelderland 16 juni 2015, ECLI:RBGEL:2015:3713 (TenneT/Alstom).

8. Rb. Gelderland 29 maart 2017, ECLI:NL:RBGEL:2017:1724. Zie bijv. ook Het Financieele Dagblad 31 maart 2017, 'Tennet krijgt schadeclaim van $€ 23,1$ miljoen toegewezen'.

9. Rb. Limburg 16 november 2016, ECLI:RBLIM:2016:9887

10. Zie bijv. Het Financieele Dagblad 23 december 2016, 'TLN start collectieve claim tegen Europese truckfabrikanten'; NRC 14 november 2016, 'Schadeclaims vrachtwagenkartel kunnen oplopen tot 100 miljard'. 
den (hierna: de Implementatiewet). Met deze wet is de Richtlijn inzake schadeclaims wegens mededingingsinbreuken (2014/104/EU) (hierna: de Richtlijn) in het Nederlandse recht omgezet. Het doel van de Richtlijn is om het voor benadeelden eenvoudiger te maken om schadevergoeding te vorderen bij inbreuken op het mededingingsrecht. In zoverre is de voorzichtige verwachting gerechtvaardigd dat het aantal kartelschadeclaims eerder zal toenemen dan afnemen.

In het onderhavige artikel zal worden ingegaan op een aantal recente ontwikkelingen op het gebied van de private handhaving van het mededingingsrecht. Daarbij wordt in het bijzonder aandacht besteed aan de voornoemde nieuwe wettelijke bepalingen als gevolg van de implementatie van de Richtlijn, alsmede aan enkele noemenswaardige ontwikkelingen in de jurisprudentie op het gebied van kartelschade. Hoewel het onderwerp zich hoofdzakelijk afspeelt op het terrein van de niet-contractuele aansprakelijkheid, is het ook interessant voor lezers van Contracteren. Niet alleen kunnen follow-on kartelschadeclaims zich voordoen in de relatie tussen contractanten - zij het op basis van onrechtmatige daad - waarbij zich bijvoorbeeld de vraag kan voordoen in hoeverre een forumkeuze of arbitragebeding van toepassing is (zie par. 4), maar ook heeft de jurisprudentie op het gebied van kartelschadeclaims interessante jurisprudentie opgeleverd die voor de contractenrechtelijk geinteresseerde jurist van belang is (zie bijvoorbeeld par. 7 over de voordeelstoerekening).

\section{Follow-on kartelschade- claims: enkele algemene karakteristieken}

De focus van deze bijdrage ligt op zogeheten follow-on schadeclaims. Dit betreft civielrechtelijke vorderingen tot schadevergoeding die worden ingesteld nadat de Europese dan wel nationale mededingingsautoriteiten een mededingingsinbreuk hebben vastgesteld. Het grote voordeel van follow-on procedures is dat het bestaan van de mededingingsinbreuk een gegeven is in de civiele procedure en daar niet meer ter discussie staat (zie hierover nader par. 6).

Follow-on kartelschadeprocedures kenmerken zich door het veelal internationale karakter. Het betreft vaak Europees-wijde kartels waarbij ondernemingen uit verschillende landen betrokken zijn. ${ }^{11}$ In een procedure gaat het dus vaak om een veelheid van, al dan niet in vrijwaring opgeroepen en tussenkomende, verwerende internationale partijen. Dit betekent dat veel kwesties die aan de orde komen tijdens deze kartelschadeprocedures, betrekking hebben op procedurele aspecten rondom bijvoorbeeld bevoegdheid en aanhouding. Zo is in meerde-

11. Verwezen wordt bijv. naar de in de inleiding genoemde follow-on procedures. re procedures aan de orde geweest of de Nederlandse rechter gehouden is de aansprakelijkheidsprocedure aan te houden indien het besluit waarin de Europese Commissie het kartel heeft vastgesteld, nog niet onherroepelijk is in verband met een nog lopende beroepsprocedure bij het Gerecht van Eerste Aanleg dan wel het Hof van Justitie (van de Europese Unie). Dit in het licht van de Unierechtelijke verplichting voor nationale rechters om zich te onthouden van een uitspraak die indruist tegen een besluit van de Commissie waarin een inbreuk op het mededingingsrecht is vastgesteld. ${ }^{12}$

Inmiddels is het duidelijk dat een zaak niet zonder meer wordt aangehouden vanwege het nog lopen van een Unierechtelijke beroepsprocedure, maar dat daaraan in de Nederlandse rechtspraak aanvullende eisen worden gesteld. Zo is er geen reden voor aanhouding als er eerst nog beslissingen moeten worden genomen over punten die geen betrekking hebben op de geldigheid van de beschikking (zoals de geldigheid van de cessies). ${ }^{13} \mathrm{En}$ in de zaak Equilib/KLM oordeelde het Hof Amsterdam dat aanhouding van de nationale procedure alleen nodig is als daarin vragen van feiten of recht aan de orde zijn waarvan de beantwoording afhangt van de geldigheid van het besluit van de Commissie. Daarvan is volgens het hof slechts sprake wanneer in redelijkheid twijfel kan bestaan aan de geldigheid van dat besluit. Redelijke twijfel aan de geldigheid van het besluit van de Commissie is dus vereist voor aanhouding. ${ }^{14}$

12. Zie art. 16 Verordening $1 / 2003$, welk artikel een codificatie vormt van HvJ 14 december 2000, C-344/98, Jur. 2000, p. I-11369 (Masterfoods). Om deze reden wordt het verweer inhoudende dat de zaak moet worden aangehouden, ook wel aangeduid als het 'Masterfoodsverweer'

13. Rb. Den Haag 1 mei 2013, ECLI:NL:RBDHA:2-13:CA1870 (CDC/Shell e.a.). Tevens wijst de rechtbank op het Unierechtelijke doeltreffendheidsbeginsel dat in gevaar zou kunnen komen bij aanhouding.

14. Hof Amsterdam 24 september 2013, ECLI:GHAMS:2013:3013 (Equilib/ $\mathrm{KLM}$ ). Hierbij is het wel de vraag in hoeverre dit standpunt Unierechtelijk toelaatbaar is. Weliswaar valt er veel voor te zeggen om de civiele procedure niet te lichtvaardig aan te houden als er eigenlijk geen aanwijzingen zijn dat het Commissiebesluit in beroep onderuit zal gaan, althans als gedaagde niet aannemelijk kan maken dat deze kans redelijkerwijs bestaat. Anderzijds bepaalt het Unierecht nu eenmaal dat er geen beslissing mag worden genomen die indruist tegen een beschikking van de Commissie. In HvJ 14 december 2000, C-344/98, Jur. 2000 , p. I-11369 (Masterfoods) heeft het Hof van Justitie geoordeeld dat 'wanneer de beslechting van het geschil voor de nationale rechter afhangt van de geldigheid van de beschikking van de Commissie, (...) de verplichting tot loyale samenwerking mee[brengt], dat de nationale rechter, om geen beslissing te nemen die tegen de beschikking van de Commissie indruist, de behandeling van de zaak schorst tot een definitieve beslissing van de communautaire rechterlijke instanties op het beroep tot nietigverklaring, tenzij hij van oordeel is, dat het in de gegeven omstandigheden gerechtvaardigd is het Hof een prejudiciële vraag over de geldigheid van de beschikking van de Commissie te stellen'. Kortom: aanhouden of vragen stellen. Er kan wel worden gezegd dat dit niet absoluut dwingend voorschrijft dat er per direct zal moeten worden aangehouden c.q er prejudiciële vragen moeten worden gesteld. Verder is ook relevant of het beroep voor de Unierechter zich alleen toespitst op de boeteomvang of ook betrekking heeft op de inbreuk op zichzelf. In het eerste geval is er immers geen discussie over de rechtsgeldigheid van het besluit ten aanzien van de inbreuk (maar alleen over de omvang van de opgelegde boete op basis van die inbreuk). Als de rechter echter vonnis wijst voordat de Unierechter zich heeft uitgelaten over de Commissiebeschikking - en deze uitspraak afhangt van de geldigheid van de beschikking -, neemt de rechter het 
Ook aspecten van internationaal privaatrecht spelen een grote rol. Vanwege de betrokkenheid van veel verschillende internationale partijen zijn vragen over het toepasselijke recht onvermijdelijk. Complicerende factor daarbij is dat een versnippering kan optreden van het toepasselijke recht. Dat hangt samen met de marktregel uit artikel 6 lid 3 sub a van de Rome II Verordening - zoals hierna wordt aangegeven is de onrechtmatige daad de meest aangewezen grondslag voor kartelschadeclaims -, op grond waarvan voor het toepasselijke recht wordt aangeknoopt bij het recht van de lidstaat waarvan de markt wordt beinvloed of waarschijnlijk wordt beinvloed door de beperking van de mededinging. Indien sprake is van bijvoorbeeld een Europees-wijd kartel, zal dit dus tot verschillende toepasselijke rechtsstelsels kunnen leiden. Om deze versnippering tegen te gaan biedt artikel 6 lid 3 sub b van de Rome II Verordening de eisende partij onder omstandigheden de mogelijkheid om op alle vorderingen het recht van het forum toe te passen, mits de markt in deze lidstaat een van de markten is die rechtstreeks en aanzienlijk zijn beinvloed door de mededingingsinbreuk. Aangezien de Rome II Verordening alleen van toepassing is op schadeveroorzakende gebeurtenissen vanaf 11 januari 2009, komt het echter nog regelmatig voor dat de Wet conflictenrecht onrechtmatige daad ('WCOD') van toepassing is. ${ }^{15}$ De WCOD kent ook de marktregel, maar zonder de mogelijkheid om te kiezen voor het recht van het forum. Niet zelden zal de Nederlandse rechter dus buitenlands recht moeten toepassen in kartelschadeprocedures.

Een andere karakteristiek betreft de betrokkenheid van claimentiteiten - meestal in de vorm van een daartoe speciaal opgerichte stichting of besloten vennootschap die de procedure als eiser voeren tegen de karteldeelnemers. Deze claimentiteiten werken veelal met een cessiemodel waarbij de benadeelde partijen hun vorderingen cederen aan de claimentiteit. In veel gevallen is ook een procesfinancier betrokken, die de procedure voorfinanciert; in zo'n situatie ontvangt de benadeelde partij bij toewijzing van de vordering een vergoeding na aftrek van de kosten die zijn gemaakt voor het voeren van de procedure. ${ }^{16}$

In verschillende procedures is de rechtsgeldigheid van de cessies van de schadevorderingen onderwerp van debat geweest, in het bijzonder waar sprake was van

risico dat zijn vonnis uiteindelijk indruist tegen het oordeel van de Unierechter. Dat lijkt een brug te ver, ook als de gedaagde (vermeende) karteldeelnemer in de civiele procedure niet aannemelijk heeft kunnen maken dat er iets schort aan het Commissiebesluit.

15. Zie over enkele overgangsrechtelijke problemen in dit verband: Y.A. Rampersad \& J.A. van der Weide, Hora ruit, tempus fluit. Boek 10 BW, WCOD, Rome II en het overgangsrecht, MvV 2017, p. 51-61.

16. Dit type arrangement valt niet onder het verbod van no cure, no pay dat voor advocaten geldt, aangezien deze afspraak wordt gemaakt tussen de benadeelde partijen en het claimvehikel. De advocaatkosten worden vergoed door het claimvehikel (al dan niet met behulp van financiering door de betrokken procesfinancier), ongeacht de uitkomst van de procedure. Het risico ligt dus bij de claimentiteit c.q. de financier. Zie hierover ook Rb. Amsterdam 13 september 2017, ECLI:RBAMS: 2017:6607, r.o. 4.27 (Equilib/KLM c.s.) claimentiteiten die de schadevorderingen hadden overgenomen van benadeelde partijen en waarbij de koopprijs afhankelijk was van de uitkomst van de procedure. Fundamentele verweren die in dit verband werden aangevoerd, waren de vermeende strijd met het fiduciaverbod en strijd met de openbare orde of goede zeden. In een recent vonnis van de Rechtbank Amsterdam zijn beide verweren verworpen. ${ }^{17}$ Het feit dat de claimentiteit een percentage van de ontvangen schadevergoeding doorgeeft aan de cedenten en de rest behoudt als onderdeel van de koopprijs, maakt de cessies niet strijdig met het fiduciaverbod. Daaraan doet niet af dat de koopprijs voor de schadevorderingen afhankelijk is van het resultaat van de procedure. ${ }^{18}$ Van strijd met de openbare orde of goede zeden is evenmin sprake. Daarbij overweegt de rechtbank dat schadevergoedingsvorderingen wezenlijk kunnen bijdragen tot handhaving van daadwerkelijke mededinging in de Europese Unie en dat bundeling van dergelijke kartelschadevorderingen via cessie aan een 'litigation vehicle' een legitiem middel is om tot een efficiënte afwikkeling van kartelschade te komen. ${ }^{19}$

\section{Grondslag voor schadevergoeding}

Om in aanmerking te komen voor schadevergoeding zal vanzelfsprekend allereerst een juridische grondslag aanwezig moeten zijn. Voor zover sprake is van schending van de Europese mededingingsregels kent deze vraag naar de grondslag twee dimensies: een Unierechtelijke en een nationale.

Het Unierechtelijke kartelverbod (art. 101 Verdrag betreffende de werking van de Europese Unie (VWEU)) brengt rechtstreeks gevolgen teweeg in de betrekkingen tussen particulieren, en doet voor de justitiabelen rechten ontstaan die de nationale rechter dient te handhaven, aldus het Hof van Justitie volgens vaste rechtspraak. Daarbij heeft het Hof van Justitie tevens duidelijk gemaakt dat eenieder vergoeding van de geleden schade kan vorderen wanneer er een causaal verband bestaat tussen die schade en een door artikel $101 \mathrm{VWEU}$ verboden mededingingsregeling. ${ }^{20}$ Ook in de preambule van de Richtlijn wordt expliciet duidelijk gemaakt dat het recht op schadevergoeding een recht is dat direct voortkomt uit het Unierecht (onderstreping auteur):

'Voor het uniale recht op vergoeding van schade die voortvloeit uit inbreuken op het mededingingsrecht van

17. Rb. Amsterdam 13 september 2017, ECLI:RBAMS:2017:6607 (Equilib/KLM c.s.).

18. Rb. Amsterdam 13 september 2017, ECLI:RBAMS:2017:6607, r.o. 4.24 (Equilib/KLM c.s.).

19. Rb. Amsterdam 13 september 2017, ECLI:RBAMS:2017:6607, r.o. 4.27 (Equilib/KLM c.s.).

20. HvJ EU 13 juli 2006, gevoegde zaken C-295/04 tot en met C-298/04, Jur. 2006, p. I-6619 (Manfredi), r.o. 61; HvJ EU 6 november 2012, C-199/11, ECLI:EU:C:2012:684 (Otis), r.o. 43 
de Unie en het nationale mededingingsrecht is het vereist dat elke lidstaat over procedurele regels beschikt die de effectieve uitoefening van dat recht garanderen.'

Kortom, het betreft hier een recht op schadevergoeding dat rechtstreeks voortvloeit uit het Unierecht. Om dit Unierecht te verwezenlijken zal echter het nationale recht nodig zijn. In zoverre zal er toch ook een nationale basis moeten zijn waarmee het Unierecht op schadevergoeding kan worden geëffectueerd. De nationale grondslag die hiervoor naar Nederlands recht het meest in aanmerking komt, betreft de onrechtmatige daad ex artikel 6:162 van het Burgerlijk Wetboek $(B W) .{ }^{21}$ Dit zowel in het geval dat er geen contractuele relatie bestaat tussen de benadeelde partij en de aangesproken karteldeelnemer, als in de situatie waarin er wel sprake is van een contractuele relatie. Dat in laatstgenoemde situatie wanprestatie niet mogelijk is als aansprakelijkheidsgrondslag, komt reeds doordat overeenkomsten in strijd met het kartelverbod (art. 6 Mededingingswet (Mw) en art. $101 \mathrm{VWEU}$ ) van rechtswege nietig zijn krachtens het Unierecht. ${ }^{22}$ In het geval van misbruik van economische machtspositie is van een zodanige Unierechtelijke nietigheid geen sprake, maar zal in de meeste gevallen ook sprake zijn van nietigheid op basis van artikel 3:40 BW. Een zodanige nietigheid levert uiteraard wel de mogelijkheid op te ageren uit hoofde van onverschuldigde betaling of ongerechtvaardigde verrijking. Een vordering op basis van ongerechtvaardigde verrijking kan ook worden ingesteld zonder dat er een contractuele verhouding bestaat tussen de benadeelde en de karteldeelnemer. Daarbij is ook samenloop mogelijk met een vordering gebaseerd op onrechtmatige daad. Veelal zal de onrechtmatige daad echter als grondslag de voorkeur hebben boven de ongerechtvaardigde verrijking, aangezien de keuze voor laatstgenoemde grondslag betekent dat de schadevergoeding is beperkt tot het bedrag van de verrijking. ${ }^{23}$ In het vervolg van deze bijdrage zal ik dan ook uitsluitend uitgaan van de onrechtmatige daad als nationale grondslag.

21. Om deze reden is de Richtlijn ook omgezet in Boek 6 in de titel handelende over de onrechtmatige daad, zoals hierna nog aan de orde zal komen. In het voorontwerp van de Implementatiewet was in art. 6:193m BW nog opgenomen dat een inbreukpleger onrechtmatig handelt jegens degene die door die inbreuk schade lijdt. Deze bepaling is niet teruggekomen in het uiteindelijke wetsvoorstel zoals dat is aangenomen. De wetgever heeft niet toegelicht waarom dit is gebeurd, maar de reden is waarschijnlijk dat - zoals ook opgemerkt tijdens de internetconsultatie - de bepaling geen toegevoegde waarde heeft naast art. 6:162 BW.

22. In het geval van misbruik van economische machtspositie is van een zodanige nietigheid van rechtswege geen sprake, maar zal in de meeste gevallen ook sprake zijn van nietigheid op basis van art. 3:40 BW.

23. Zie ook I.P.M Ligteringen, Privaatrechtelijke gevolgen van een schending van het mededingingsrecht (serie Onderneming en Recht), Deventer: Kluwer 2016, p. 163-164.

\section{Forumkeuze en arbitragebeding}

Hoewel de grondslag voor schadevergoeding dus veelal zal worden gevonden in de buitencontractenrechtelijke aansprakelijkheidsgrond van de onrechtmatige daad, sta ik kort stil bij de betekenis van eventuele forumkeuzeof arbitrageclausules in overeenkomsten tussen karteldeelnemers en hun benadeelde partij als contractant (het gaat dan dus om directe afnemers).

\subsection{Forumkeuzebedingen}

In het arrest CDC/Akzo Nobel heeft het Hof van Justitie zich uitgelaten over de toepasselijkheid van een forumkeuzebeding bij vorderingen die zijn gebaseerd op inbreuken op het mededingingsrecht. ${ }^{24}$ Daarin oordeelde het Hof van Justitie dat een forumkeuzebeding enkel kan gelden voor geschillen die zijn ontstaan of zullen ontstaan in verband met een bepaalde rechtsbetrekking en zich enkel uitstrekt tot geschillen die zijn ontstaan in de rechtsbetrekking naar aanleiding waarvan het beding is overeengekomen. Op zichzelf is een forumkeuzebeding voor mededingingsinbreuken mogelijk, maar daarvoor is wel vereist dat dit voldoende duidelijk is. Er moet namelijk worden vermeden dat een partij wordt verrast doordat een bepaald gerecht is aangewezen om kennis te nemen van geschillen die hun oorsprong vinden in andere betrekkingen dan die naar aanleiding waarvan de forumkeuze is bedongen. Daarom geldt een forumkeuzebeding dat abstract verwijst naar geschillen die in contractuele betrekkingen ontstaan, niet voor een geschil waarin een medecontractant betrokken raakt wegens een verbintenis uit onrechtmatige daad wegens een inbreuk op het mededingingsrecht. Dat de scope van dit beding zich zou uitstrekken tot mededingingsinbreuken, is dan niet voorzienbaar.

Het Hof Amsterdam heeft in de zaak Kemira/CDC in het natriumchloraatkartel met verwijzing naar voornoemd arrest van het Hof van Justitie geoordeeld dat, anders dan Kemira betoogde, de forumkeuzebedingen niet van toepassing waren op de vorderingen gebaseerd op aansprakelijkheid wegens mededingingsinbreuken. Daarvoor was het forumkeuzebeding te abstract geformuleerd. ${ }^{25}$

\subsection{Arbitragebedingen}

Naar Nederlands recht is de lijn die geldt voor forumkeuzebedingen doorgetrokken naar arbitragebedingen. In het voornoemde arrest Kemira/CDC oordeelde het hof dat 'er geen goede grond [is] om anders te oordelen ten aanzien van de arbitragebedingen'. Ook ten aanzien van deze arbitragebedingen geldt dat de benadeelde ondernemingen niet hebben ingestemd met de toepassing ervan op vorderingen die voortvloeien uit inbreu-

HvJ EU 21 mei 2015, C-352/13, EU:C:2015:335 (Cartel Damage Claims Hydrogen Peroxide SA/Akzo Nobel NV e.a)

25. Hof Amsterdam 21 juli 2015, ECLI:NL:GHAMS:2015:3006 (Kemira/ CDC). 
ken op het mededingingsrecht, aldus het hof. De Rechtbank Rotterdam kwam tot hetzelfde oordeel in de civiele procedure in het liftenkartel. ${ }^{26}$

Ondanks dat arbitragebedingen niet onder het toepassingsbereik vallen van de EEX-Verordening (herschikking), lijkt het inderdaad voor de hand te liggen dezelfde benadering te hanteren als bij forumbedingen. In sommige andere lidstaten wordt soms echter tot een andere conclusie gekomen. Zo heeft het Engelse High Court in de zaak Microsoft Mobile OY (Ltd)/Sony Europe Limited geoordeeld dat het toepassingsgebied van een algemeen arbitragebeding zich wel uitstrekte tot vorderingen gebaseerd op schending van het mededingingsrecht. $^{27}$ En ook een Duitse (lagere) rechter kwam onlangs tot een soortgelijk oordeel. ${ }^{28}$

\section{De Richtlijn en Implementatiewet}

\subsection{Richtlijn 2014/104/EU}

Private handhaving van mededingingsrecht heeft al geruime tijd de aandacht van de Europese Commissie. In aanvulling op de administratieve handhaving is het doel om de privaatrechtelijke handhaving door schadevergoedingsvorderingen door private partijen die zijn benadeeld door een mededingingsinbreuk, te stimuleren. Dit heeft uiteindelijk geculmineerd in de Richtlijn, die uiterlijk 27 december 2016 moest zijn omgezet in het nationale recht van de lidstaten. In Nederland is dit gebeurd met de Implementatiewet van 25 januari $2017 .{ }^{29}$ De Richtlijn is van toepassing op inbreuken van artikel 101 VWEU (kartelverbod) en artikel 102 VWEU (misbruik economische machtspositie) en op nationale bepalingen - lees: artikelen 6 en $24 \mathrm{Mw}$ - die in een zaak parallel met deze Europese artikelen worden toepast ('parallelle toepassing'). Zuiver nationale inbreuken van het mededingingsrecht - dat wil zeggen: schending van artikelen 6 en/of $24 \mathrm{Mw}$ zonder dat ook sprake is van schending van de Unierechtelijke artikelen 101 en/of 102 VWEU - vallen niet onder de Richtlijn.

Rb. Rotterdam 25 mei 2016, ECLI:NL:RBROT:2016:4164 (Stichting De Glazen Lift/Kone e.a.)

27. High Court 28 februari 2017, [2017] EWHC 374 (Ch). De High Court overwoog in dit verband o.a.: '(...) the mere fact that a claim in contract has not been pleaded is, to my mind, irrelevant. Were the manner in which a case was actually pleaded to matter, instead of how a case could have been pleaded, it would be easy for a claimant to circumvent the scope of an arbitration or jurisdiction clause by selectively pleading or not pleading certain causes of action. It would be an extraordinary outcome were a claimant successfully to be able to contend that, because a contractual claim had not been pleaded, a "parallel" claim in tort arising out of exactly the same facts and with a scope defined by that contract fell outside the scope of such a provision. The proposition only has to be stated to be rejected' (r.o. 72(ii))

28. Landgericht Dortmund 13 september 2016, ECLI:DE:LGDO:2017:0913.

29. Op het moment van schrijven van onderhavig artikel is de Richtlijn in nagenoeg alle lidstaten omgezet in het nationale recht, met uitzondering van Griekenland en Portugal.
De bepalingen uit de Richtlijn vormen deels een codificatie van rechtspraak van het Hof van Justitie. Het gaat dan bijvoorbeeld om algemene uitgangspunten dat eenieder recht heeft op vergoeding van de schade die deze (rechts)persoon heeft geleden als gevolg van een inbreuk op het mededingingsrecht. Daarnaast bevat de Richtlijn specifieke bepalingen over onder meer toegang tot bewijsmateriaal, de doorwerking van beslissingen van nationale mededingingsautoriteiten, verjaringstermijnen, hoofdelijke aansprakelijkheid, doorberekening van meerkosten en schadebegroting.

\subsection{Implementatiewet privaatrechtelijke handhaving mededingingsrecht}

De reikwijdte van de Implementatiewet sluit aan bij die van de Richtlijn. Ook de omzettingsbepalingen zijn dus uitsluitend van toepassing op schending van de Unierechtelijke mededingingsregels en situaties van parallelle toepassing en niet op zuiver nationale inbreuken. Het is overigens geen fundamentele keuze van de wetgever om schadevorderingen op grond van nationale mededingingsinbreuken (vooralsnog) anders te behandelen dan schadevorderingen die zijn gebaseerd op een Unierechtelijke inbreuk. De beperking tot het Unierecht heeft te maken met het toepasselijke wetgevingsbeleid bij de omzetting van Europese richtlijnen. Op grond van de Aanwijzingen voor de regelgeving worden in de implementatieregeling geen andere regels opgenomen dan voor de implementatie noodzakelijk zijn (de zogeheten zuivere implementatie). ${ }^{30}$ Inmiddels is er echter het wetsvoorstel Wijziging markt en overheid, concentratietoezicht en privaatrechtelijke handhaving. Onderdeel van dit wetsvoorstel is dat de bepalingen over privaatrechtelijke handhaving van het mededingingsrecht voortaan ook van toepassing zullen zijn op zuiver nationale mededingingsinbreuken. Dit ligt ook voor de hand. $\mathrm{Er}$ is geen reden om zuiver nationale inbreuken minder gunstig te behandelen dan Unierechtelijke inbreuken. ${ }^{31}$

De Implementatiewet waarmee de Richtlijn is omgezet, heeft geleid tot de invoering van een nieuwe afdeling in titel 3 (onrechtmatige daad) van Boek 6 van het Burgerlijk Wetboek. Een aparte afdeling was volgens de wetgever aangewezen, omdat de richtlijnbepalingen weliswaar deels aansluiten bij een aantal uitgangspunten van Nederlands recht, maar ook een aantal uitzondingen daarop bevatten. Ook zijn er wijzigingen in het Wetboek van Burgerlijke Rechtsvordering (Rv) die met name betrekking hebben op de bewijskracht van een inbreukbeschikking van de Autoriteit Consument en Markt (art. 161a Rv) en op de toegang tot bescheiden in zaken betreffende mededingingsinbreuken (art. 844 t/m 850 Rv).

Niet alle bepalingen van de Richtlijn hebben geleid tot wetswijziging, omdat het Nederlandse recht op deze

30. Aanwijzing 9.4 van de Aanwijzingen voor de regelgeving

31. Volgens de ontwerptoelichting is $40 \%$ van de besluiten van de Autoriteit Consument en Markt gebaseerd op alleen nationaal mededingingsrecht. Zie voor het wetsvoorstel: <www.internetconsultatie.nl/ wijzigingmarktenoverheid $>$. 
punten volgens de wetgever reeds aan de Richtlijn voldeed. Voor sommige bepalingen was dat vanzelfsprekend. Het vereiste uit de Richtlijn dat de volledige schade als gevolg van een mededingingsinbreuk voor vergoeding in aanmerking moet kunnen komen (met inbegrip van rente), is bijvoorbeeld geen bepaling die actieve omzetting behoeft in het Nederlandse recht. Voor sommige andere bepalingen ligt dit echter minder voor de hand. Het betreft bijvoorbeeld het bewijsvermoeden bij het doorberekeningsverweer (zie hierna par. 7.1). ${ }^{32}$

\subsection{Inwerkingtreding en overgangsrecht}

De Richtlijn bepaalt dat er geen terugwerkende kracht mag worden gegeven aan de nationale omzettingsmaatregelen ter naleving van de materiële bepalingen van de Richtlijn. Voor andere omzettingsmaatregelen (dus procedurele bepalingen) geldt dat deze niet van toepassing mogen zijn op vorderingen tot schadevergoeding die vóór 26 december 2014 bij een nationale rechterlijke instantie aanhangig zijn gemaakt. De Richtlijn verschaft geen duidelijkheid welke bepalingen uit de Richtlijn als materiële bepalingen moeten worden beschouwd.

Ten aanzien van vorderingen die zijn ontstaan vóór de inwerkingtreding van de Richtlijn, dient met de Richtlijn toch rekening te worden gehouden. Dit volgt uit hetgeen de Hoge Raad heeft overwogen in het arrest TenneT/ABB: ${ }^{33}$

'Hoewel de Richtlijn temporeel niet het onderhavige geval bestrijkt en het beoordelingskader dus wordt gevormd door het Nederlandse recht - met inachtneming van het gelijkwaardigheidsbeginsel en het doeltreffendheidsbeginsel $(. .$.$) - is het wenselijk om dat recht zo$ uit te leggen dat het leidt tot uitkomsten die verenigbaar zijn met de Richtlijn.'

Voor zover dit oordeel is gebaseerd op de Unietrouw, heeft dat naar mijn mening niet alleen te gelden bij toepassing van het Nederlandse recht (ter verwezenlijking van het EU-recht op schadevergoeding), maar evenzeer bij toepassing door de Nederlandse rechter van een buitenlands nationaal recht dat op de vordering van toepassing is op basis van het conflictenrecht.

\section{Onrechtmatigheid, causaliteit en schade}

Dat sprake is van een onrechtmatige gedraging staat in follow-on kartelschadeprocedures in principe niet ter discussie. Voor zover het gaat om een mededingingsinbreuk die is vastgesteld in een beschikking van de Europese Commissie is de nationale rechter gebonden aan dit

32. Zie voor een overzicht van de implementatiebepalingen o.a. E.-J. Zippro, Het voorontwerp van de implementatiewet richtlijn privaatrechtelijke handhaving mededingingsrecht, MvV 2015, p. 343-354.

33. HR 8 juli 2016, ECLI:NL:HR:2016:1483. oordeel. ${ }^{34}$ En sinds de invoering van artikel 161a Rv ter implementatie van de Richtlijn - levert een onherroepelijk besluit van de Autoriteit Consument en Markt onweerlegbaar bewijs op van de vastgestelde inbreuk in een procedure waarin schadevergoeding wordt gevorderd wegens een inbreuk op het mededingingsrecht. ${ }^{35}$

Voor beslissingen van mededingingsautoriteiten van andere lidstaten geldt een ander regime. Onder de Richtlijn geldt dat een zodanig oordeel van een buitenlandse mededingingsautoriteit moet kunnen gelden als prima facie bewijs van het bestaan van een mededingingsinbreuk. Bij de implementatie van de Richtlijn heeft de wetgever opgemerkt dat deze bepaling geen omzetting behoeft, aangezien de Nederlandse rechters hier op basis van de vrije bewijsleer reeds van uit kunnen gaan. ${ }^{36}$

Het nieuwe artikel 6:1931 BW bepaalt dat een kartel wordt vermoed schade te veroorzaken. Dit is een weerlegbaar vermoeden, waarbij het aan de inbreukmaker is om het tegendeel aannemelijk te maken. Het bewijsvermoeden helpt benadeelde partijen in hun procedures tegen de karteldeelnemers, aangezien het aantonen van de nadelige effecten van een kartel meestal geen sinecure is. Daarvoor is niet zelden de overlegging van (kostbare) economische deskundigenrapporten noodzakelijk. Met het bewijsvermoeden wordt de bal in eerste instantie bij de aangesproken karteldeelnemers gelegd, die zullen moeten ontzenuwen dat van schade als gevolg van het kartel sprake is geweest. Overigens zal het in de praktijk in veel gevallen voor de eisende partij uiteindelijk toch nog wel nodig blijken te zijn om een deskundige in te schakelen ter weerspreking van hetgeen de gedaagde karteldeelnemers aanvoeren ter ontzenuwing van het bewijsvermoeden. Desalniettemin is het bewijsvermoeden vanuit het perspectief van de benadeelde partijen een vooruitgang. Sommige landen zijn zelfs nog verder gegaan. Zo kent Hongarije het vermoeden dat een kartel leidt tot een prijsverhoging van $10 \%$. ${ }^{37}$

Een specifiek type schade dat in de context van kartelinbreuken voorkomt, is de schade die het gevolg is van zogeheten 'umbrella-effecten'. Het gaat daarbij om schade die wordt geleden door afnemers van producenten die niet deelnemen aan het kartel, maar die hun prijzen als gevolg van dit kartel op een hoger niveau hebben vastgesteld dan zonder dit kartel het geval zou zijn geweest. Deze niet-deelnemende partijen hebben hun

34. Zie art. 16 van Verordening $1 / 2003$, welk artikel een codificatie vorm van HvJ 14 december 2000, C-344/98, Jur. 2000, p. I-11369 (Masterfoods).

35. Voor de invoering van art. 161a Rv bestond er discussie over de gebondenheid van de civiele rechter aan de beslissing van de ACM op grond van het beginsel van de formele rechtskracht (in het bijzonder de horizontale werking van de formele rechtskracht). Het is waarschijnlijk dat de wetgever om deze reden is overgegaan tot omzetting van deze richtlijnbepaling in art. 161a Rv.

36. Kamerstukken II 2015/16, 34490, 3, p. 8 .

37. Dit is neergelegd in de Hongaarse mededingingswet. Deze bepaling bestaat sinds 1 juni 2009 en dus voordat de Richtlijn werd aangenomen 
prijzen zogezegd onder de paraplu van het kartel kunnen vaststellen. Het Hof van Justitie heeft in het arrest Kone duidelijk gemaakt dat ook de schade door deze paraplu-effecten dient te worden vergoed door de karteldeelnemers. ${ }^{38}$ Dit betekent dat kartellisten schade dienen te vergoeden die is ontstaan doordat benadeelde partijen te veel hebben betaald voor hun producten of diensten bij ondernemingen die geen onderdeel uitmaakten van het kartel. Uiteraard kan bij de toekenning van deze schadevergoeding geen regres worden genomen door de karteldeelnemer bij de onderneming die onder de paraplu van het kartel haar prijzen hoger (dan zonder het kartel) heeft kunnen vaststellen. Laatstgenoemde onderneming heeft immers niet deelgenomen aan het kartel en is daarvoor niet (hoofdelijk) aansprakelijk.

Een andere vraag bij het bepalen van de schadebegroting betreft de na-effecten (run-off effects) van het kartel. Indien het kartel tot een einde komt (veelal doordat de Commissie invallen heeft gedaan), zullen de effecten van dit kartel op de markt niet direct zijn verdwenen. Daar kan nog een bepaalde tijd overheen gaan. Gedurende een bepaalde periode na afloop van het kartel kan er dus nog steeds sprake zijn van schade.

\section{7. (De kwalificatie van) het passing-on verweer}

\subsection{Het doorberekeningsverweer}

Een bekend verweer van kartellisten is het passing-on verweer (of: doorberekeningsverweer), waarbij wordt betoogd dat eventuele hogere kosten door de afnemer van het kartel zijn doorbelast aan de indirecte afnemers. In het verleden werd soms de vraag opgeworpen in hoeverre het Unierecht in de weg zou staan aan een dergelijk verweer, aangezien dit het verhaal van kartelschade moeilijker zou maken en daarom wellicht in strijd zou zijn met het doeltreffendheidsbeginsel. Inmiddels bestaat over de toelaatbaarheid van het passing-on verweer geen enkele discussie meer. De mogelijkheid van het doorberekeningsverweer is expliciet opgenomen in de Richtlijn. Daarbij is ook aandacht besteed aan de moeilijkheden die kunnen ontstaan bij vorderingen door de directe en indirecte afnemers. Aangezien het voor indirecte afnemers lastig kan zijn om aan te tonen dat er doorberekening van de meerkosten heeft plaatsgevonden (en er dus schade is geleden door de indirecte afnemer), is in de Richtlijn een weerlegbaar bewijsvermoeden opgenomen. Dit gaat uit van het vermoeden dat een doorberekening heeft plaatsgevonden van het te veel betaalde bedrag aan de indirecte afnemers indien door de indirecte afnemer wordt aangetoond dat (1) de ver-

38. HvJ EU 5 juni 2014, zaak C-557/12 (Kone). Zie R. Meijer, Prijsvorming onder de paraplu van het kartel: aansprakelijkheid van karteldeelnemers voor schade door 'umbrella pricing'? HvJ EU 5 juni 2014, zaak C-557/12 (Kone e.a./ÖBB-Infrastuktur), M\&M 2014, p. 181-185. weerder een inbreuk op het mededingingsrecht heeft gemaakt, (2) deze inbreuk heeft geleid tot meerkosten voor de directe afnemer, en (3) de indirecte afnemer goederen of diensten heeft afgenomen waarop de mededingingsinbreuk betrekking had. De Nederlandse wetgever heeft het niet noodzakelijk gevonden om dit bewijsvermoeden te implementeren, aangezien deze bewijslastverdeling reeds uit artikel $150 \mathrm{Rv}$ zou volgen. Dit lijkt ervan uit te gaan dat het passing-on verweer een bevrijdend ('ja, maar') verweer is. Dat is het geval indien het passing-on verweer wordt beschouwd als een beroep op voordeelstoerekening. Het zou anders (kunnen) liggen als het verweer wordt geplaatst in de context van het schadebegrip. Dit brengt ons bij de vraag naar de kwalificatie van het passing-on verweer.

\subsection{Voordeel of schade?}

In de Nederlandse literatuur waren de meningen namelijk verdeeld hoe het passing-on verweer naar Nederlands recht moet worden gekwalificeerd: als schadeverweer of als beroep op voordeelstoerekening. De Hoge Raad heeft in het arrest TenneT/ABB het (verlossende) antwoord gegeven. ${ }^{39}$ Dit antwoord luidde enigszins verrassend dat het doorberekeningsverweer zowel kan worden opgevat als onderdeel van de schadeberekening als kan worden geplaatst in de sleutel van de voordeelstoerekening van artikel 6:100 $\mathrm{BW}$. In beide benaderingswijzen gaat het er volgens de Hoge Raad om dat het door de benadeelde in verband met de schadeveroorzakende gebeurtenis behaalde voordeel dient te worden betrokken in de toe te kennen schadevergoeding, voor zover dat redelijk is. Het arrest heeft vele pennen in beroering gebracht. $^{40}$

Los van de zuiver nationale dogmatische aspecten is interessant hoe dit oordeel zich verhoudt tot het Unierecht en in het bijzonder tot de verplichtingen die voortvloeien uit de Richtlijn. In dit verband moet met name worden gedacht aan het bewijsvermoeden dat sprake is van doorberekening van de meerkosten aan de indirecte afnemer. De Hoge Raad ziet in de stelplicht en bewijslast geen reden om te kiezen voor de ene dan wel andere benadering. Volgens de Hoge Raad geven de regels bij het bepalen van de omvang van de schade, waaronder artikel 6:97 BW, voldoende ruimte om, net zoals bij de voordeelstoerekening, de stelplicht en de bewijslast bij de aansprakelijke partij te leggen. Hoewel de rechter ontegenzeggelijk veel ruimte heeft bij de schadebegroting, blijft normaal gesproken toch het uitgangspunt dat de bewijslast van de betwisting van (de omvang van) de

39. Zie bijv. HR 8 juli 2017, ECLI:NL:HR:2016:1483 (TenneT c.s./ABB c.s) over de vraag of een passing-on verweer moet worden beschouwd een beroep op voordeelstoerekening of als onderdeel van de schadebegroting.

40. Zie o.a. A.L.M. Keirse \& M. van Kogelenberg, Schadebegroting bij een doorberekeningsverweer en een bijgestelde maatstaf voor voordeelstoerekening, Contracteren 2016, p. 97-109; W.H. van Boom, Doorgeschoven kartelschade:schadeberekening of voordeelstoerekening?, AA 2017, p. 41-46; J.A. Möhlman \& M.R. Fidder, TenneT/ABB: een mijlpaal voor kartelschade én het algemene schadevergoedingsrecht, MvV 2016, p. 262-269 
schade op de aangesproken partij rust (hier: de karteldeelnemer). De Hoge Raad geeft in feite aan dat het wettelijke systeem voldoende flexibel is om hiervan af te wijken en dat de rechter dat in dit specifieke geval ook zal moeten doen om aan de Richtlijn te voldoen. Een richtlijnconforme interpretatie brengt dan dus mee dat moet worden uitgegaan van een bewijsvermoeden. Naar mijn mening was de koninklijke route echter geweest om het bewijsvermoeden wettelijk te verankeren. ${ }^{41}$

\section{Hoofdelijkheid}

Het is bepaald geen absoluut gegeven dat benadeelde partijen alle inbreukmakende ondernemingen in dezelfde procedure aanspreken voor de als gevolg van het kartel geleden schade. Aangezien sprake is van een hoofdelijke aansprakelijkheid, kan een benadeelde partij ervoor kiezen alleen de partijen met de diepste zakken te dagvaarden of alleen de partij die in hetzelfde land als de benadeelde is gevestigd. De gedaagde ondernemingen zullen dan meestal willen overgaan tot oproeping in vrijwaring van de niet gedaagde karteldeelnemers met het oogmerk om bij toewijzing van de vordering regres te nemen op deze andere hoofdelijk aansprakelijke ondernemingen. De Richtlijn bevat in artikel 11 een uitgebreide regeling over hoofdelijkheid. Deze regeling gaat uit van het principe dat inbreukplegers hoofdelijk aansprakelijk zijn, maar formuleert daarop een aantal uitzonderingen. Zo kunnen kleine en middelgrote inbreukmakende ondernemingen in beginsel alleen worden aangesproken door hun eigen directe en indirecte afnemers, onder de voorwaarde dat hun marktaandeel op de relevante markt tijdens de inbreuk minder dan $5 \%$ bedroeg en de regels van hoofdelijkheid hun economische levensvatbaarheid onherstelbaar in gevaar zou brengen. De Europese wetgever heeft kortom willen voorkomen dat deze kwetsbare partijen met een beperkt marktaandeel zouden omvallen door de regels over hoofdelijkheid. Deze regels zijn geimplementeerd in artikel 6:193m BW.

Een speciale positie neemt de onderneming in die immuniteit heeft gekregen in het kader van het clementiebeleid. Krachtens artikel 11 lid 5 van de Richtlijn is de ontvanger van immuniteit slechts jegens zijn directe en indirecte afnemers en leveranciers hoofdelijk verbonden tot vergoeding van de schade die voortvloeit uit de inbreuk, tenzij geen volledige vergoeding van schade kan worden verkregen van de andere bij de inbreuk betrokken ondernemingen. De reden hiervoor is dat het clementiebeleid zeer belangrijk is voor het opsporen van kartelinbreuken en dat de Europese wetgever heeft willen voorkomen dat de bereidwilligheid van ondernemingen om clementie aan te vragen (teneinde boete-immuniteit te krijgen) zou afnemen. Het is dus een vrij oppor-

41. Zoals eerder reeds betoogd in R. Meijer \& E.-J. Zippro, Elk nadeel heb zijn voordeel, (bewijslast)problematiek rondom het passing-on verweer in kartelschadezaken, M\&M 2016, p. 220-226. tunistische - of netter: rechtspolitiek ingegeven - bepaling. De bepaling is geimplementeerd in artikel $6: 193 \mathrm{~m}$ lid 4 BW.

\section{Verjaring en stuiting}

De Richtlijn heeft ook geleid tot een apart verjaringsregime voor kartelschadevorderingen. In artikel 6:193s $\mathrm{BW}$ is thans een subjectieve termijn opgenomen van vijf jaar na aanvang van de dag volgende op die waarop de inbreuk is stopgezet en de benadeelde met de inbreuk, de daaruit voortvloeiende schade en de daarvoor aansprakelijke persoon bekend is geworden. In ieder geval verjaart de vordering door verloop van twintig jaar na aanvang van de dag waarop de inbreuk is stopgezet. In vergelijking met het bestaande systeem van artikel 3:310 BW is artikel 6:193s BW slachtoffervriendelijker nu het startpunt van de verjaring zowel bij de korte subjectieve termijn als bij de lange objectieve termijn is gekoppeld aan het stopzetten van de inbreuk.

Een andere verandering betreft de verlenging van de verjaringstermijn gedurende de periode waarin een mededingingsautoriteit onderzoek verricht of een procedure voert met betrekking tot een mededingingsinbreuk waarop de vordering betrekking heeft. Deze verlenging begint een dag na het verstrijken van de verjaringstermijn en eindigt een jaar na de vaststelling van een definitieve inbreukbeslissing of het op andere wijze beëindigen van de procedure. Ook deze bepaling, die is neergelegd in artikel 6:193t lid 2 BW, biedt benadeelde partijen meer zekerheid dat hun vorderingen niet komen te verjaren. ${ }^{42}$

\section{Tot slot}

Hiervoor zijn enkele recente en belangrijke ontwikkelingen besproken op het gebied van de private handhaving van het mededingingsrecht, meer in het bijzonder follow-on kartelschadeclaims. Dit betreft geenszins een volledig overzicht, maar het toont wel aan dat er veel beweging zit in dit rechtsgebied. Waar de eerste golf van jurisprudentie zich hoofdzakelijk concentreerde op de meer procesrechtelijke vragen, verschuift de focus - nu deze kwesties (in ieder geval deels) zijn uitgekristalliseerd - naar vragen van meer materiële aard. Een goed voorbeeld hiervan betreft de fundamentele uitspraak over de kwalificatie van het passing-on verweer. Verder zijn de komende periode vragen te verwachten over de uitleg van de Richtlijn en de omzetting daarvan in het recht van de lidstaten. ${ }^{43}$

42. Een procedure tot buitengerechtelijke geschillenbeslechting vormt eveneens een verlengingsgrond ex art. 6:193 $\mathrm{t}$ lid $1 \mathrm{BW}$.

43. Naar verluidt heeft de Portugese Tribunal Judicial da Comarca de Lisboa prejudiciële vragen gesteld over de uitleg van de Richtlijn. De zaak is bij het Hof van Justitie bekend onder zaaknummer C-637/17 (Cogeco Communications). Verdere gegevens zijn nog niet beschikbaar op het moment van schrijven van dit artikel. 